\title{
Personality and Axiological Predictors of Adaptation to the Life Situation of an Emigrant and His Family - Based on the Example of Polish Emigrants in the Netherlands
}

\section{Introduction}

The phenomenon of emigration is one of the new challenges of the twentyfirst century. This scale has increased over the past decades. The reason for this, is the opening of the borders of the Schengen Group countries and the growing importance of the European Union in Europe. ${ }^{1}$ The opening of borders meant that the emigration phenomenon concerns not only about Poland, but also the whole of Europe. Another motif why this phenomenon should be described thought a scientific perspective is the demographic crisis $^{2}$, which is the consequence of retiring people from the so-called

1 P. Dąbrowski, J. Napierała, A. Piekut, Migracje międzynarodowe: Polska - Unia Europejska - Europa Wschodnia, „Biuletyn Migracyjny” 14 (2007), p. 1-10.

2 J. Świętoniowska, Starzenie się społeczeństwa europejskiego w kontekście kryzysu światowego. Czy UE nadal ma szansę stać się najbardziej konkurencyjna gospodarką światową?, „Zeszyty Naukowe Zakładu Europeistyki” 3 (2009), nr. 11, p. 86-105. 
generations of baby boomers. ${ }^{3}$ Emigration is usually featured in terms of sociology, but literature on research in the field of family psychology is very poor. This article will show a different perspective of emigration, because it will study a specific group of Poles abroad, namely those who live in the Netherlands. In the literature, there are relationships between individual personality items and the level of adaptation to difficult situations, such as emigration. The model of Paul Costa and Robert McCrae have shown implications of such relationships, especially if one speaks of extraversion, openness to experience, conscientiousness and agreeableness. In turn, neuroticism can be a factor disturbing the adaptation process. The value system, based on Rokeach's theory has also been shown to be a possible, predictor of social adaptation. ${ }^{4}$

\section{Emigration}

The term "migration" derives from the Latin word "migratio", which means a wandering or transferring the inhabitants of a given country or region. The reasons for the emigration phenomenon are equipotential. In sociological theories, the reasons include the economic reasons, i.e. labor migration, or those that comes from political reasons such as war and persecution. The closest term to „migration” is „emigration”. Emigration means voluntarily leaving home country. The last term is „immigration” (Latin: „immigro”), which refers to people who come to a receiving country. Migrating can be considered in many ways. First of all in terms of its duration, i.e. settlement, short-term, long-term, shuttle. There are many typologies of migration, but the most classic one is that created by William Petersen. ${ }^{5}$ He introduced two types of migration: innovative and conservative. The first objective is to make changes and take action, the anticipated consequence of which is to create something new. In turn, the second refers to maintaining the status

\footnotetext{
3 Baby boomers to określenie grupy społecznej ludzi urodzonych podczas powojennego wyżu demograficznego w latach 1946-1964.

$4 \quad$ P. T. Costa, R. R. McCrae, Revised NEO Personality Inventory (NEO-PI-R) and NEO Five-Factor Inventory (NEO-FFI) professional manual, Odessa 1992.

5 W. Petersen, A General Typology of Migration, „American Sociological Review” 53 (1958), p. 256-266.
} 
quo. Among the conservative migration, it refers to the basic classes, for example voluntary and forced migration. ${ }^{6}$

The problem of emigration is not only a political matter, it also applies to individual psychological problems, individuals, but also entire families who are affected by the problem of changing their original place of residence. A change so extreme requires adaptation. States should, of course, create conditions for adaptation to be effective, but the personality predispositions for adaptation are crucial. In the context of sources in the field of psychology, it is noticed that an emigrant has to face the loss of what he has lost, leaving his country, also to try to provide basic things such as accommodation, work, documentation necessary to start living in a new country. Attention is also drawn to the initial lack of social contacts that may exacerbate stress in the emigrant. ${ }^{7}$

It is also noted that in countries that had a high level of emigration at the beginning of the 21st century, most of the children of immigrants suffered from an absent parent syndrome. Parents absence have a very negative influence on the child. In autobiographical studies, the young generation spoke about the feeling of being lost, depressed, fearful and having a lack of self-confidence. These states often required psychotherapy. ${ }^{8}$

\section{Adaptation process}

Emigration creates the possibility of starting new life for the a family in most places in the world, but it is undoubtedly also, one of the stressful situations in which an individual has to face new crises with which he has never had contact before. In publications in the field of psychology, many definitions of "adaptation” can often be found. Z. Skorny ${ }^{9}$, distinguishes between adaptation to the external environment (adaptation to the requirements of the environment and choosing social roles) and the internal environment (refers to the human personality that is shaped at the moment of adaptation).

\footnotetext{
$6 \quad$ A. Górny, Kaczmarczyk P., Uwarunkowania i mechanizmy migracji zarobkowych w świetle wybranych koncepcji teoretycznych, „Instytut Studiów Społecznych UE” 49 (2003), p. 10-21.

J. Kubitsky, Psychologia migracji, Warszawa 2012.

$8 \quad$ M. Colson, Coping with absent parents, Hastings 2011.

9 Z. Skorny, Mechanizmy regulacyjne ludzkiego działania, Warszawa 1989.
} 
A person who has a high level of adaptation, is active, brings new activities to his community and creates an environment for the self-fulfillment of other people, which enables its own development. ${ }^{10}$ The authors note the necessity of a person adapting to internal change in order to survive. The moment when there are no changes, or when they are inadequate to the situation, then one can talk about the lack of adaptation. ${ }^{11}$

Another Polish psychologist, Kazimierz Dąbrowski, ${ }^{12}$ poses the question about the mental health of an individual predisposed to adapting to a new situation. In his deliberations, he draws attention to the relation between the ability to adapt and mental health. Adaptation can have four dimensions: a) positive adaptation; b) positive maladjustment; c) negative adaptation; d) negative maladjustment. By positive adaptation, the author understands positive adaptation to a value of a higher level value, ${ }^{13}$ and maladjustment to primitive attitudes. A positively adapted person is one who sets goals that bring him closer to a particular individual and social ideal. Such a person aims at individual development in such a way as to be someone who brings something valuable to society. Positive maladjustment means isolation from primitive, instinctual values at the social and individual level. This type of maladjustment is creative, it characterizes people with developmental independence. Stanisław Popek calls this state "social nonconformity", which means independence in the aspect of thinking and actions, based on your own attitude, built from individual values ordered in the hierarchy. ${ }^{14}$ Positive nonconformity should also be seen as the ability to defend one's point of view, despite social pressure. It is very important that a person who is unadapted positively cannot be focused on breaking

10 J. Śliwak, U. Reizer, J. Partyka, Poczucie osamotnienia a przystosowanie społeczne, „Studia Socialia Cracoviensia” 7 (2015), nr. 1, p. 61-78.

11 T. Tomaszewski, O możliwościach jednostki w sytuacjach przemian społecznych, „Kolokwia Psychologiczne” 2 (1993), nr. 11, p. 20-28.

12 K. Dąbrowski, Wprowadzenie do higieny psychicznej, Warszawa 1979.

13 Values of higher level considered by Dąbrowski are divided into individual and social values. The individual aspects includes talents and feelings, exclusive feelings, awareness of one's own identity and history, development, and empathy, autonomy, responsibility, authenticity, and a high level of social awareness in the essence of society. The occurrence of an individual and social essence is a condition sine qua non of the existence of a higher-level value.

R. E. Bernacka, Osobowościowy mechanizm konformizmu i nonkonformizmu - specyfika funkcjonowania i przejawy w zachowaniu, „Psychologia rozwojowa” 2 (2005), nr. 2, p. 73-82. 
social norms. ${ }^{15}$ Adaptation and positive maladjustment is recognized by Dąbrowski as mental health. In the process of upbringing, shaping these two adaptive attitudes are the basis of mental hygiene. ${ }^{16}$ Negative adaptation, often unconscious, means adapting to the conditions and requirements of the environment, so that only primitive benefits can be derived from it in such a way that others will suffer damage. This form of adaptation most often occurs in people with mental disorders. Negative conformism, Popek proposes is an adaptation that blocks creative features in a human being, not only in the cognitive but also in the behavioral sphere. ${ }^{17}$ Negative maladjustment is characterized in people whose attitude in interaction with society is inadequate. When in contact with others such persons, react contrary to generally accepted axiological assumptions, social requirements and standards, sometimes also by being aggressive. There are many similarities than can be transferred to the emigration field when drawing on the definition of adaptation of Kazimierz Dąbrowski and the theory of Stanisław Popek.

The concept of adaptation by Kazimierz Dąbrowski points to the implications of adaptation to mental health, relative to a strong hierarchy of values, expressed by conformism and nonconformity. Understanding adaptation as the ability to meet your own needs in a specific environment through self-activity determines personality development at a higher level. ${ }^{18}$

\section{The role of personality in the process of adaptation}

Personality and the individual determinants can be very crucial in the context of the prediction style adaptation. G. W. Allport ${ }^{19}$ notes that human personality is a unique structure in which the knowledge of behaviors and intentions contributes to determining the direction of future aspirations.

\footnotetext{
15 E. Aronson, T. D. Wilson, R. M. Akert, Psychologia społeczna, Poznań 1997.

16 K. Dąbrowski, Trud istnienia, Warszawa 1975.

17 S. Popek, Kwestionariusz Twórczego Zachowania KANH, Lublin 2000.

18 K. Dąbrowski, Trud istnienia, Warszawa 1975.

19 G. W. Allport, Becoming: Basic considerations for a psychology and personality, New Haven 1955
} 
Personality has a significant impact in the context of adaptation to stressful situations. This is evidenced by the Kobasa research. ${ }^{20} 250$ people participated in the research and were members of the management staff of public utilities. At the beginning of the study, data regarding health status, stress load and personality was obtained. It turned out that people with a lower personality immunity showed twice as many disease symptoms than people with a more resistant personality, regardless of stress conditions. ${ }^{21}$

Many studies relate to the personality theory of Paul Costa and Robert McCrae. Among the factors mentioned by the authors are the following dimensions of personality: a) neuroticism, b) extraversion, c) openness to experience, d) agreeableness; e) conscientiousness. In studies connected with neuroticism, it is noticed that highly neurotic people are characterized by irrational thinking. They make an effort to control their own impulse. Stress situations cause tremendous tension. People who have this characteristic are prone to hostility and unjustified anger. In addition, their self-esteem is very low. People with low levels of neuroticism are balanced and able to relax. They experience less stress and tension and they adapt better to new situations. ${ }^{22}$

Another factor is extraversion, whose high level determines cordial and social behavior. People like that are inclined to stimulate themselves through interpersonal contacts. In addition, a cheerful mood and optimistic life prevail among such people. The opposite pole of this factor is introversion, which describes those who prefer to regain their strength through solitude and distance themselves from social relations. Introverts are usually shy people. $^{23}$

The relationship between neuroticism and extraversion, in the individual's process to adapt to stressful situations, was sought by H. Eysenck. ${ }^{24} \mathrm{He}$ believes that balanced sanguine extroverts, who have a maximum average level of neuroticism and an above-average level of extraversion, have great adaptation

\footnotetext{
20 S. C. Kobasa,, Commitment and coping in stress resistance among lawyers, „Journal of Personality and Social Psychology" 42 (1982), p. 707-717.

21 S. C. Kobasa, Stressful life events, personality and health: An inquiry into hardiness, „Journal of Personality and Social Psychology” 37 (1979), p. 1-11.

22 B. Zawadzki, J. Strelau, P. Szczepaniak, M. Śliwińska, Inwentarz osobowości NEO-FFI Costy i McCrae. Adaptacja polska. Podręcznik, Warszawa 1998.

23 J. Strelau, Psychologia. Podręcznik Akademicki³, Gdańsk 2000.

24 H. Eysenck, Opis i pomiar osobowości, „Psychologia wychowawcza” 3 (1960), nr. 19, p. 3-14.
} 
skills. In the „better adapted” group, he mentions also phlegmatics, people who have low or average levels of neuroticism and extraversion below the average. It can be concluded that practitioners, social activists or intellectuals are usually among the most adaptive. The worst adapted are melancholics and cholerics, who are characterized by emotional instability.

People with a high openness to experiences, regardless of whether they have to transform their external or internal world, are characterized by a high degree of creativity. Aesthetic sensitivity and the desire to develop in an intellectual context may cause a person to question authorities, but at the same time, to try to learn new values of a political and social nature. Little openness is represented by people who are conservative, not only in their views, but also in behavior. Changes cause discomfort to such people. High openness to experience is a constitutive element of self-development. ${ }^{25}$ A qualitative research carried out with a group of Polish emigres in London, indicate openness as a primary feature, a predictor of adaptation to emigration. ${ }^{26}$

People with high agreeableness are people who are willing to help and be kind to other people, provided that they represent similar values. You can describe these people as honest, straightforward and empathetic for others. Agreeableness correlates with less difficulties in interpersonal relationships and rare situations of conflicts with the law. In turn, people with low agreement are competitive. Research confirms that agreeableness is a factor facilitating adaptation to crisis situations. ${ }^{27}$

The last factor is conscientiousness. A high level of this feature indicates a strong will and motivation to achieve the goals set at the start. Meticulousness and punctuality provide highly conscientious people with broadly understood success. People with little conscientiousness do not perform their duties diligently and do not have specific life goals. This leads to a laziness that limits adaptation to new conditions. Conscientiousness is a feature correlating with high adaptation to changing living conditions. ${ }^{28}$

\footnotetext{
25 A. H. Maslow, Motywacja i osobowość, Warszawa 1990.

26 K. Winiecka, Adaptacja społeczna rodzin młodych migrantów polskich mieszkających w Londynie, Wrocław 2015.

27 S. Nikodemska, Struktura JA, obraz siebie i radzenia sobie w sytuacji trudnej, u pacjentów lecznictwa odwykowego, „Świat Problemów” 129 (2003), nr. 10, p. 4-7.

28 J. Cieciuch, Ksztaltowanie się systemu wartości od dzieciństwa do wczesnej dorosłości, Warszawa 2013.
} 


\section{Life values and adaptive behaviors}

The vital values of an individual are equally important from the point of view of adaptive behaviors. Maria Misztal points out that "values are phenomena from the sphere of consciousness, for which the coexistence of cognitive, emotional and normative components is specific. In addition to knowledge about the emotional object of the relationship, the element constituting the value is the belief that the given object, state of affairs or way of acting is the right and socially acceptable object of human desires and aspirations." ${ }^{29}$

H. P. Hollander thinks that ${ }^{30}$ values are closely related to the main segments of attitudes, so they can determine behavior in such a way as to achieve certain goals. In turn, Kazimierz Dąbrowski ${ }^{31}$ states that the hierarchy of values based on "higher feelings" is a chance for a person to develop. In addition, the author points to the relationship between the hierarchy of values and personality. He believes that values aimed at interpersonal relationships and the conscious pursuit of development are the main determinants of personality development from an individual and social perspective. A more elaborate theory that refers to values is the one that was created by Milton Rokeach. ${ }^{32}$ According to him, values are closely related to the personality. A system of individual beliefs, in other words a personality consists of three components:

a) descriptive values - are evaluated for truthfulness (true; false);

b) evaluative values - in other words evaluating (good, bad);

c) prescriptive and proscriptive values - adjudicate that the object of conviction is desirable or not (prescriptive, prohibitive). ${ }^{33}$

Rokeach, on the basis of his concept, developed the Value Scale, which examines the system of values characteristic for young people and adults. In the Value Scale, two basic value groups can be seen:

a) ultimate values - they refer to the purpose of human existence, a characteristic feature is that they are superstitious (personal and social);

29 M. Misztal, Wykształcenie jako wartość, Warszawa 1984.

30 H. R. Hollander, Current Perspectives in Social Psychology of Education, New York 1971.

K. Dąbrowski, Pasja rozwoju, Warszawa 1988.

M. Rokeach, The Nature of Human Values, New York-London 1973.

33 J. Kościuch, Kwestionariusz Wartości Miltona Rokeacha, „Studia Philosophiae Christianae” 1 (1983), nr. 19, p. 224-231. 
b) instrumental - these are ways to realize ultimate values (moral and competence).

Rokeach argued that by examining the hierarchy of values, there is the possibility of understanding the human personality and strategies that occur in the course of psychosocial development. ${ }^{34}$ Brunon Hołyst ${ }^{35}$ notes that in a situation where material goods, or work, is only an instrumental character - meaning a means to implement other means, all kinds of crises are temporary and they are insignificant. However, in a situation in which instrumental values become an end in itself, serious personality disorders can occur. The high meaning of the ultimate values means that the person will not function without crises, but that his or her personality potential will be developed. The situation of emigration is an extremely crisis-inducting moment. The hierarchy of values and the distribution of individual final and instrumental values can be a sign of the individual's mental health and how he adapts to the changes that occur in his life. The advantage of the importance of ultimate values over instrumentals values gives greater stability to the individual and facilitates his adaptation process.

\section{Methods and materials}

Thise research aims to determine whether and what interdependencies occur between adaptation and personality and adaptation and the values professed by the Polish emigrants. The metrics include: sex, age, education and having a family in exile.

\subsection{Research problems}

Referring to the review of the literature presented in the previous parts of this work, the following research questions were identified:

1. Are personality traits related to the level of adaptation of an emigrant living in the Netherlands?

34 B. Mróz, 20 lat później - osobowość i hierarchia wartości wybitnych aktorów polskich. Badania podłużne, Warszawa 2015.

35 T. Gałkowski, Rola systemu wartości w procesie psychicznego i społecznego rozwoju jednostki, s. 56-61, in: B. Hołyst, System wartości i zdrowie psychiczne, Warszawa 1990. 
2. Is the hierarchy of values related to with the adaptation to a new life situation as is emigration?

3. Does having a family during emigration help for better adaptation?

\subsection{Hypothesis}

Taking into account the above research questions, the following research hypotheses were formulated:

1. There are connections between emigrant personality traits and its adaptation to emigrate.

1.1. High neuroticism is associated with low adaptation to emigration.

1.2. High conscientiousness, agreeableness, openness and extraversion are associated with high level of adaptation.

2. There are relations between the hierarchy of values of emigrants and their adaptation.

2.1. Among the final values: mature love, social recognition and protection of the family's existence are positively related with adaptation.

2.2. The high position of instrumental values such as loyalty, responsibility and helpfulness is associated with a high level of adaptation.

3. People leaving with the family are better adapted to live in emigration.

\subsection{Respondents}

The analysis included $n=200$. Among the subjects were women $(n=100)$ and men $(n=100)$, aged 20 to 55 , the average age of the subjects $M=32.86$, and the standard deviation was $\mathrm{SD}=8.594$.

\subsection{Procedure of research}

This study was conducted using the questionnaire method among Poles who live in the Netherlands. Respondents participating in the study received a uniform set of test batteries. Its composition included: a reference (gender, age, education and marital status), as well as three psychometric questionnaires: a) This Item Personality Inventory (TIPI-PL); b) Rokeach Value Scale (RVS); c) Scale of Life Change (SZŻ). The study was conducted 
in the Netherlands from March 1 to July 30, 2018. Subjects had unlimited time to complete all tests.

\subsection{Research tools}

\subsubsection{Personality - Ten Item Personality Inventory}

For the measurement of personality the test used was the Ten Item Personality Inventory that meets psychometric requirements that relate to accuracy and reliability. The questionnaire consists of 10 items, of which two adjectives correspond to one personality items. The sheet is consistent with personality traits, in the NEO-FFI Costa and McCrae inventory. Five dimensions of personality were examined: neuroticism, extraversion, conscientiousness, openness to experience and agreeableness. The subject's task is to respond to ten pairs of statements, which remain on a 7-point scale, from 1 - which means „definitely disagree”, up to 7 - meaning „I strongly agree”. The result of all scales is the average of two positions. One of the positions is reversed. The described tool has satisfactory internal compliance ratios. Based on the reliability analysis carried out, it was found that Cronbach's alpha coefficients for particular items in the Polish language version are as follows: a) openness $-\alpha=0.45$; b) agreeableness $-\alpha=0.54$; c) conscientiousness $\alpha=0.80 ; d$ ) neuroticism $-\alpha=0.83 ;$ e) extraversion $-\alpha=0.74$.

\subsubsection{Values - Rokeach Value Scale}

This tool examines the values. The scale consists of two lists of values: 18 final values and 18 instrumental values. The final values in the sheet include: 1) the convenience of life, 2) exciting life, 3) intellectual achievements, 4) world peace, 5) beauty of the world, 6) equality, 7) durability, 8) happiness, 9) freedom, 10) internal harmony, 11) mature love, 12) national security, 13) pleasure, 14) salvation, 15) self-care, 16) social recognition, 17) true friendship, 18) wisdom. Instrumental values are: 1) ambition;2) the width of intellectual horizons; 3) abilities; 4) charm, personal charm; 5) cleanliness; 6) courage; 7) the ability to forgive; 8) caring; 9) honesty; 10) creative imagination 11) independence; 12) intellectualism, 13) logic 14) love; 15) obedience, 16) politeness; 17) responsibility; 18) self-control.

The highest positions in the hierarchy and the lowest ones are the most stable values, the medium positions are the most susceptible to change. The 
test can be carried out individually, but also in groups. In order to estimate the reliability of the tool, a test-retest method is proposed that allows the assessment of the stability results.

\subsubsection{Adaptation - The scale of life changes}

The Life Change Scale is a self-report tool. It is used to measure the effects of crisis situations. The questionnaire examines: beliefs about the meaning of life, a sense of personal strength, depth of relationship with others, change in the value system and enrichment of spiritual life. High scores on these scales are considered „posttraumatic growth”, which means positive change or positive adaptation. In turn, the low result is interpreted as a lack of adaptation to a stressful situation. The Life Changes Scale has 19 items, has satisfactory convergence and criterion accuracy. There is internal compliance also at a satisfactory level. The responses in the questionnaire are of a five-point scale (from „definitely decreased” to "definitely increased"). The value of the coefficient of reliability (Cronbach's $\alpha$ ) is 0.80 for adults who are in the period of two years from the critical event; 0.90 for people whose lives were in danger. The Guttman half division indicates the reliability of 0.71 . The inter-luminal correlation is 0.51 .

\subsubsection{Other variables}

In addition to the variables mentioned, a sociodemographic data was collected, ie age, sex, education, and family membership at the place of emigration.

\subsection{Results}

The results were analyzed in the STATISTICA 12.5 program. Initially, the normality of the distribution of variables was verified and analyzed. The Shapiro-Wilk test was used. This test showed that the collected data have a distribution different from the normal distribution, because all analyzes indicated that the significance level was $p=0.00 ; p<0.05$. Therefore, nonparametric statistical tests were used to verify test hypotheses. 


\subsubsection{Personality and adaptation to emigration}

Since the distribution for the variable adjustment was different from the normal distribution in order to determine the correlation between the personality traits and adjustment the rho-Spearman correlation test was conducted. The results are presented in Tab. 1.

Tab. 1. Personality and adaptation to emigration

\begin{tabular}{|l|c|c|c|c|}
\hline Variables & N current & Spearman's rho & $\mathrm{T}(\mathrm{n}-2)$ & $\mathrm{p}$ \\
\hline Adaptation and extraversion & 200 & 0,33 & 3,83 & 0,00 \\
\hline Adaptation and agreeableness & 200 & 0,20 & 2,29 & 0,02 \\
\hline Adaptation and conscientiousness & 200 & 0,22 & 2,55 & 0,01 \\
\hline Adaptation and neuroticism & 200 & $-0,19$ & $-2,09$ & 0,04 \\
\hline Adaptation and openness & 200 & 0,26 & 2,95 & 0,00 \\
\hline
\end{tabular}

The results show that extraversion significantly correlates with the level of adaptation. Based on the obtained correlation coefficient, the dependence force can be defined as the average $(\mathrm{p}<0.001)$. A positive direction means that the higher the extraversion, the higher the level of adjustment to emigration. Openness also has a positive correlation with adaptation to difficult situations. The relation of the strength of compounds remains on the average level $(\mathrm{p}<0.01)$. Furthermore, agreeableness and conscientiousness also show a connection with average adaptation $(\mathrm{p}<0.05)$. The only variable that shows the reverse direction of the relationship with the adaptation is neuroticism $(\mathrm{p}<0.05)$. That means that the higher the neuroticism, the less adaptation to life in emigration. Thus, the first hypothesis is confirmed.

\subsubsection{Relation of the value hierarchy with adaptation}

In order to consider whether there are significant dependencies, between instrumental and final values, among emigrants, a non-parametric correlation of rho-Spearman was conducted.

Tab. 2. Adaptation and final values

\begin{tabular}{|l|c|c|c|c|}
\hline Variable final values & N current & rho Spearmana & $\mathrm{T}(\mathrm{N}-2)$ & $\mathrm{p}$ \\
\hline Adaptation and national security & 200 & $-0,08$ & $-0,90$ & 0,37 \\
\hline Adaptation and mature love & 200 & $-0,23$ & $-2,60$ & 0,01 \\
\hline Adaptation and wisdom & 200 & $-0,44$ & $-5,32$ & 0,00 \\
\hline Adulation and beauty of the world & 200 & $-0,06$ & $-0,68$ & 0,50 \\
\hline Adaptation and peace in the world & 200 & $-0,37$ & $-4,24$ & 0,00 \\
\hline Adaptation and real friendship & 200 & $-0,15$ & $-1,67$ & 0,10 \\
\hline
\end{tabular}




\begin{tabular}{|l|c|c|c|c|}
\hline Adapting pleasure from life & 200 & $-0,09$ & $-0,93$ & 0,35 \\
\hline Adaptation and equality of people & 200 & $-0,19$ & $-2,13$ & 0,04 \\
\hline Adaptation and life successes & 200 & 0,010 & 0,11 & 0,91 \\
\hline Adaptation and self-respect & 200 & $-0,29$ & $-3,30$ & 0,00 \\
\hline Adaptation and social recognition & 200 & $-0,02$ & $-0,32$ & 0,75 \\
\hline $\begin{array}{l}\text { Adaptation and internal peace and } \\
\text { harmony }\end{array}$ & 200 & $-0,23$ & $-2,56$ & 0,01 \\
\hline Adaptation and personal freedom & 200 & $-0,28$ & $-3,12$ & 0,00 \\
\hline $\begin{array}{l}\text { Adaptation and safeguarding a being } \\
\text { for the family }\end{array}$ & 200 & $-0,31$ & $-3,48$ & 0,00 \\
\hline Adaptation and salvation & 200 & $-0,20$ & $-2,17$ & 0,03 \\
\hline Adaptation and health & 200 & $-0,29$ & $-3,33$ & 0,00 \\
\hline $\begin{array}{l}\text { Adaptation and life full of impres- } \\
\text { sions }\end{array}$ & 200 & $-0,19$ & $-2,14$ & 0,03 \\
\hline
\end{tabular}

The analysis shows that there are negative dependencies, between adaptation to life in emigration, and such final values as: mature love, wisdom, peace in the world, equality of people, self-respect, inner peace, personal freedom, safeguarding of being for the family, salvation, health and life full of impressions. Among them there are only significantly correlated values. The obtained correlation coefficients are in the range of -0.19 to -0.34. The strength of significant relationships varies from weak to average. Among the ultimate values characterizing high adaptation, on the basis of the hypotheses are: mature love and safeguarding a being for the family. Social recognition is irrelevant.

Tab. 3. Adaptation and instrumental values

\begin{tabular}{|l|c|c|c|c|}
\hline & $\mathrm{N}$ & rho Spearmana & $\mathrm{T}(\mathrm{N}-2)$ & $\mathrm{p}$ \\
\hline Variable instrumental values & 200 & $-0,05$ & $-0,48$ & 0,63 \\
\hline Adaptation and ambition & 200 & $-0,09$ & $-0,96$ & 0,34 \\
\hline Adaptation and cleanliness & 200 & $-0,14$ & $-1,55$ & 0,12 \\
\hline Adaptation and willingness to love & 200 & $-0,18$ & $-1,96$ & 0,05 \\
\hline Adulation and politeness & 200 & $-0,21$ & $-2,42$ & 0,02 \\
\hline Adaptation and logic of thinking & 200 & $-0,16$ & $-1,70$ & 0,10 \\
\hline Adaptation and loyalty & 200 & $-0,21$ & $-2,30$ & 0,02 \\
\hline Adaptation and responsibility & 200 & $-0,09$ & $-0,97$ & 0,34 \\
\hline Adaptation and courage & 200 & $-0,20$ & $-2,18$ & 0,03 \\
\hline Adaptation and self-control & 200 & $-0,22$ & $-2,40$ & 0,18 \\
\hline Adaptation and ingenuity & 200 & $-0,10$ & $-1,03$ & 0,31 \\
\hline Adaptation and obedience & 200 & $-0,19$ & $-2,12$ & 0,04 \\
\hline
\end{tabular}




\begin{tabular}{|l|c|c|c|c|}
\hline Adaptation and reflexivity & 200 & 0,00 & 0,05 & 0,96 \\
\hline Adaptation and independence & 200 & $-0,25$ & $-2,67$ & 0,00 \\
\hline Adaptation and tolerance & 200 & $-0,07$ & $-0,73$ & 0,47 \\
\hline Adaptation and honesty & 200 & $-0,23$ & $-2,52$ & 0,01 \\
\hline Adaptation and helpfulness & 200 & $-0,38$ & $-4,39$ & 0,00 \\
\hline Adaptation and forbearance & 200 & 0,00 & 0,10 & 0,92 \\
\hline
\end{tabular}

The results indicate the existence of negative relationships between the adaptation of the respondents to emigration and such instrumental values as: logical thinking, responsibility, self-control, ingenuity, reflexivity, tolerance, helpfulness and forbearance. The correlation coefficients range from -0.19 to -0.38 . The strength of these dependencies is between weak and aver a ge. Among the instrumental values which according to the hypothesis, are the predictor of a high level of adaptation are: responsibility and helpfulness. Loyalty is a value that does not correlate significantly with variable adaptation. Analyzing the meaning of final and instrumental values, it was shown that the majority of variables of a social nature, i.e. mature love, family security, responsibility and helpfulness, significantly correlate with variable adaptation. In other cases, no significant correlations were recorded. Therefore, the hypothesis is refuted.

\subsubsection{Adaptation and family of emigrant}

Initially, in order to check the normality of the distribution, the ShapiroWilk test was performed for the dependent variable adaptation. It turned out that $\mathrm{p}=0.00 ; \mathrm{p}<0.05$. The distribution was therefore different from normal. On this basis, the non-parametric U Mann-Whitney test was performed. The results are presented in Tab. 4.

Tab. 4. Adaptation and having a family on emigration

\begin{tabular}{|c|c|c|c|c|c|}
\hline \multicolumn{5}{|c|}{ Grouping variable: Emigrating with family } & \\
\hline Variable: & $\mathrm{U}$ & $\mathrm{Z}$ & $\mathrm{P}$ & $\begin{array}{c}\text { No } \\
\mathrm{N}=106 \\
\mathrm{M}(\mathrm{SD})\end{array}$ & $\begin{array}{c}\text { Yes } \\
\mathrm{N}=94 \\
\mathrm{M}(\mathrm{SD})\end{array}$ \\
\hline Adaptation & 2679,00 & $-5,64$ & $0,00^{* * *}$ & $60,03(5,00)$ & $72,60(6,32)$ \\
\hline
\end{tabular}

${ }^{*} p<0,05 \quad{ }^{* *} p<0,01 \quad{ }^{* * *} p<0,001$ 
It turned out that there are statistically significant differences between emigrants and non-migrants with the family in the level of adaptation, because the significance level $\mathrm{p}=0.00 ; \mathrm{p}<0.001$. Taking into account descriptive statistics, it can be stated that people emigrating with their families $(M=72.60)$ are better able to adapt to emigration in comparison to people living abroad without emigration $(\mathrm{M}=60.03)$. On the basis of the results presented, we can indicate that the hypothesis regarding the differences between emigrants and non-migrants with the family in terms of the level of adaptation is confirmed.

\section{Discussion}

The obtained test results confirmed a significant part of the hypotheses. There are relations between the constituent factors of the personality of emigrants and their adaptation to the conditions of emigration. Conscientiousness, agreeableness, extroversion and openness to experience turned out to be moderately, statistically significant in connection with the adaptation. That means that the high ratio of these features is associated with a better adaptation to life changes in emigration. The only personality feature that can make adaptation difficult is neuroticism. High scores in this subscale mean less probability of psychological adaptation. The results of the research, which confirm the conclusions to the first hypothesis, can also be found in the literature. According to the theory of the features of the Big Five, McCrae and Costa, ${ }^{36}$ results associated with neuroticism, characterize people who often experience negative emotional states. This may result in less faith in one's own abilities and leads to difficulties in adapting to new, stressful events.

Confirmation that extraversion is a factor that helps a person adapt to new situations can be also found in research. Extroverts are characterized by a great need for social interaction. Such people are active and energetic. This means there are people who have the ability to experience joy frequently. Many researchers confirm, ${ }^{37}$ that extroverts are more likely to use a foreign

\footnotetext{
36 B. Zawadzki, J. Strelau, P. Szczepaniak, M. Śliwińska, Inwentarz osobowości NEO-FFI Costy i McCrae. Adaptacja polska. Podręcznik, Warszawa 1998.

37 P. Skehan, Individual Differences in Second Language Learning, London 1989.
} 
language they have learned during classes. Such an activity can be particularly valuable when emigrating, because then there is an increase in interaction with the new society. It was also shown that openness to experience may be a predicator of higher adaptation to emigration. Openness to experience is, in other words, a tendency to display curiosity of a cognitive nature and a lot of tolerance for all kinds of new things. Researchers point out that the low level of this characteristic is characteristic of conservative people who do not change their views. This is undoubtedly a feature facilitating adaptation, and on the other hand, it provokes exploration in search of new experiences. In order to investigate this relationship, the motivation to leave one's mothercountry should also be taken into account in future studies. ${ }^{38}$ Regarding agreeableness, which also showed moderate statistical characteristics with adaptation, it should be noted that, according to researchers, this feature is closely related to trust in other people. In addition, such people are characterized by a focus on cooperation. They also have an altruistic motivation for behavior. However, it is also indicated that people who have high agreeableness are willing to make concessions with those who have a similar hierarchy of values. The Netherlands is certainly a country different from Poland in terms of values. Investigating the hierarchy of values among Poles going to other countries and the hierarchy of values that is most characteristic of the countries to which they emigrate, could show motivational connections, the choice of this and not another country, in order to settle. ${ }^{39}$ The last variable studied within the personality was conscientiousness. According to the hypothesis, it turned out that people with high conscientiousness will be better adapted to emigration than people with low conscientiousness. The relationship between the variables was moderate. Based on research, you can see that conscientious people, are people with a high level of compulsiveness. They carry out their work diligently and are very persistent in their activities if their goal is concrete. The trait can moderately facilitate the adaptation to emigration, because the most frequent group of emigrants are those who work abroad.

The second hypothesis, which was the concentration of final and instrumental values on those of a social nature, i.e. mature love, social

38 K. Kmiecik-Baran, Poczucie osamotnienia - charakterystyka zjawiska, „Przegląd Psychologiczny" 4 (1988), p. 1081-1095.

39 J. Cieciuch, Kształtowanie się systemu wartości od dzieciństwa do wczesnej dorosłości, Warszawa 2013. 
recognition and safeguarding of being for the family, loyalty, responsibility and helpfulness, was refuted. Social recognition and loyalty are unconfirmed values. Other values such as mature love, family security, helpfulness and responsibility appear in many studies. ${ }^{40}$ These values are an expression of social adaptation. The study of values is an extremely important area of research since according to Dąbrowski, the implementation of human values, higher feelings, is an important component of mental health, which is closely related to individual development, but also to the development of man in society. The third hypothesis, which was a high adaptation to emigration of people who left together with the family, was confirmed. This is in line with the research on shuttle emigration, which leads to the breakdown of social ties, and this, in turn, to experiencing a deeper trauma of social change. ${ }^{41}$

\section{Bibliography}

Allport G. W., Becoming: Basic considerations for a psychology and personality, New Haven 1955.

Aronson E., Wilson T. D., Akert R. M., Psychologia społeczna, Poznań 1997. Bernacka R. E., Osobowościowy mechanizm konformizmu i nonkonformizmu - specyfika funkcjonowania $i$ przejawy w zachowaniu, „Psychologia rozwojowa" 2 (2005), nr. 2, p. 73-82.

Cieciuch J. Kształtowanie się systemu wartości od dzieciństwa do wczesnej dorosłości, Warszawa 2013.

Colson M., Coping with absent parents, Hastings 2011.

Costa P. T., McCrae R. R., Revised NEO Personality Inventory (NEO-PI-R) and NEO Five-Factor Inventory (NEO-FFI) professional manual, Odessa 1992.

Czerniawska M., Empatia a system wartości, „Przegląd Psychologiczny” 45 (2002), nr. 1, p. 7-18.

Dąbrowski K., Trud istnienia, Warszawa 1975.

40 M. Czerniawska, Empatia a system wartości, „Przegląd Psychologiczny” 45 (2002), nr. 1, s. 7-18.

41 A. Pawlak, Psychospołeczne uwarunkowania zdrowia emigrantów $i$ ich rodzin $w$ świetle własnych badań jakościowych, „Przegląd Socjologiczny” 61 (2012), nr. 2, s. 177-203. 
Dąbrowski K., Wprowadzenie do higieny psychicznej, Warszawa 1979.

Dąbrowski K., Pasja rozwoju, Warszawa 1988.

Dąbrowski P., Napierała J., Piekut A., Migracje międzynarodowe: Polska Unia Europejska - Europa Wschodnia, „Biuletyn Migracyjny” 14 (2007), p. 1-10.

Eysenck H., Opis i pomiar osobowości, „Psychologia wychowawcza” 3 (1960), nr. 19, p. 3-14.

Hollander H. R., Current Perspectives in Social Psychology of Education, New York 1971.

Gałkowski T., Rola systemu wartości w procesie psychicznego i społecznego rozwoju jednostki, p. 56-61.

Hołyst B., System wartości i zdrowie psychiczne, Warszawa 1990.

Górny A., Kaczmarczyk P., Uwarunkowania i mechanizmy migracji zarobkowych $w$ świetle wybranych koncepcji teoretycznych, „Instytut Studiów Społecznych UE” 49 (2003), p. 10-21.

Kmiecik-Baran K., Poczucie osamotnienia - charakterystyka zjawiska, „Przegląd Psychologiczny" 4 (1988), p. 1081-1095.

Kobasa, S. C., Stressful life events, personality and health: An inquiry into hardiness, "Journal of Personality and Social Psychology” 37 (1979), p. 1-11.

Kobasa, S. C., Commitment and coping in stress resistance among lawyers, "Journal of Personality and Social Psychology" 42 (1982), p. 707-717.

Kościuch J., Kwestionariusz Wartości Miltona Rokeacha, „Studia Philosophiae Christianae" 1 (1983), nr. 19, p. 224-231.

Kubitsky J., Psychologia migracji, Warszawa 2012.

Kumaniecki K., Słownik łacińsko-polski, Warszawa 1964.

Maslow A. H., Motywacja i osobowość, Warszawa 1990.

Misztal M., Wykształcenie jako wartość, Warszawa 1984.

Mróz B., 20 lat później - osobowość i hierarchia wartości wybitnych aktorów polskich. Badania podłużne, Warszawa 2015.

Nikodemska S., Struktura JA, obraz siebie i radzenia sobie w sytuacji trudnej, u pacjentów lecznictwa odwykowego, „Świat Problemów” 129 (2003), nr. 10, p. 4-7.

Pawlak. A., Psychospołeczne uwarunkowania zdrowia emigrantów i ich rodzin w świetle własnych badań jakościowych, "Przegląd Socjologiczny” 61 (2012), nr. 2, p. 177-203. 
Petersen W., A General Typology of Migration, „American Sociological Review" 53 (1958), p. 256-266.

Popek S., Kwestionariusz Twórczego Zachowania KANH, Lublin 2000.

Rokeach M., The Nature of Human Values, New York-London 1973.

Skehan P., Individual Differences in Second Language Learning, London 1989. Skorny Z., Mechanizmy regulacyjne ludzkiego działania, Warszawa 1989.

Sorokowska, A., Słowińska A., Zbieg A., Sorokowski P., Polska adaptacja testu Ten Item Personality Inventory (TIPI) - TIPI-PL-wersja standardowa $i$ internetowa, Wrocław 2014.

Strelau J., Psychologia. Podręcznik Akademicki³, Gdańsk 2000.

Śliwak J., Reizer U., Partyka J., Poczucie osamotnienia a przystosowanie społeczne, „Studia Socialia Cracoviensia” 7 (2015), nr. 1, p. 61-78.

Świętoniowska J., Starzenie się społeczeństwa europejskiego w kontekście kryzysu światowego. Czy UE nadal ma szansę stać się najbardziej konkurencyjna gospodarką światową?, „Zeszyty Naukowe Zakładu Europeistyki” 3 (2009), nr. 11, p. 86-105.

Tomaszewski T., O możliwościach jednostki w sytuacjach przemian społecznych, „Kolokwia Psychologiczne” 2 (1993), nr. 11, p. 20-28.

Winiecka K., Adaptacja społeczna rodzin młodych migrantów polskich mieszkających $w$ Londynie, Wrocław 2015.

Zawadzki B., Strelau J., Szczepaniak P., Śliwińska M., Inwentarz osobowości NEO-FFI Costy i McCrae. Adaptacja polska. Podręcznik, Warszawa 1998. 